\title{
Physical Properties of Edible Films from Pangasius catfish Bone Gelatin-Breadfruits Strach with Different Formulations
}

\author{
Rian Adhi Santoso", Yoni Atma ${ }^{\# *}$ \\ \# Department of Food Science and Technology, Faculty of Bioindustry, Universitas Trilogi, Kalibata, Jakarta 12760, Indonesia \\ *Corresponding author, e-mail: yoniatma@trilogi.ac.id
}

\begin{abstract}
This research aims to provide edible film made from fish bone gelatin of Pangasius catfish mixed breadfruit starch with different formulations. The study was carried out through three stages including breadfruit starch isolation, edible films fabrication and analysis of physical properties of resulted edible film such as thickness, water vapor transmission, tensile strength and percent of elongation as well as moisture content. Edible films which were formulated from fish bone gelatin of Pangasius catfish by breadfruit starch addition have thickness values ranged of $0.084-0.123 \mathrm{~mm}, 6.08-16.77 \%$ of moisture content, water vapor transmission of 1.07 $1.60 \mathrm{~g} / \mathrm{m}^{2} / \mathrm{hour}$, tensile strength of $0.245-1.186 \mathrm{MPa}$, and percent of elongation around $70-87.14 \%$. The edible films from gelatin of Pangasius catfish bone with breadfruit starch addition have physical characteristic which fulfill the standard requirements issued by Japanese Industrial Standard (JIS)
\end{abstract}

Keywords — edible film; biodegradable materials; fish gelatin; breadfruit starch; food packaging

\section{INTRODUCTION}

Biodegradable packaging is an environmentally friendly packaging which produced from organic materials. Although they are easy to decomposed, however, they still remain a waste if we are eating their containments. Fortunately, there is another type of packaging which also originated from organic materials. Besides they are protecting food or containments, they also can be consumed. This packaging namely edible packaging or edible film packaging. According to Putra et al. (2017), edible film is thin layer of that edible (safety for consuming) materials that used as packaging in order to provide a barrier toward external factors which stimulating food deterioration such as moisture, oxygen, light and contaminants [1] . Mostly, materials to synthetizing of edible films including hydrocolloids (proteins, polysaccharides and alginates) and lipids (fatty acids, acyl glycerol, and or waxes). Edible films also can be produced from two or more of hydrocolloid and or lipid. Among these sources, gelatin has been widely used and developed in order to obtain appropriate edible film materials [2].

Gelatin is a type of protein produced by partial hydrolysis of collagen. It is mostly extracted from skin, bone, and animal tissues. Optimum extraction resulting gelatin yield around 14$15 \%$ (calculated from raw materials weight) [3]. Actually, gelatin is widely produced from cows and pigs, but they have limitations related socio-cultural and health aspects. Therefore, currently, many studies trying to found an alternative gelatin. One alternative source of gelatin is fishbased gelatin. Gelatin extracted from bone of Pangasius catfish is most potential in term of gelatin yield and physicochemical characteristics. Gelatin tend to form thin and elastic layers which transparent and digestible. Based on these properties, gelatin has the potential to be used as a raw material for making edible films. So that, producing edible film from this gelatin is promising. However, edible film based on fish gelatin has some weaknesses such as low compactness and gel strength [4]. Therefore, it is necessary to mixed gelatin with other polymers such as starch.

Starch has been used in edible film fabrication. It is because starch improves elongation degree of films because of its amylose content [5]. Studies toward edible films from gelatin and starch already done by Hendra et al. (2015) which was using tapioca and gelatin [6] and Hasdar et al. (2011) by combination of chicken leg skin gelatin with soy protein isolate [7]. In this paper, we provide edible film which made from fish bone gelatin mixed breadfruit starch with different concentrations. Breadfruit contains large portion of starch (about 60\%), unfortunately their utilization was limited, although this commodity can be found in almost all regions in Indonesia.

\section{MATERIAL AND METHODS}

This research was carried out through three stages, the first stage was breadfruit starch isolation, second stage was producing edible films and the third stage was the analysis of 
edible film characteristics such moisture content, thickness, water vapor transmission, tensile strength and percent of elongation.

\section{A. Breadfruit starch isolation}

Procedure for starch extraction was done according to method described by Akanbi et al (2009) with few modifications [8]. Firstly, breadfruit was peeled, sliced in appropriate size and then soaked into sodium metabisulfite solution for 15 minutes. After that, the fruit blanched for 7 minutes at $80{ }^{\circ} \mathrm{C}$ and crushed using blender to obtain breadfruit slurry. Next, slurry added with water in ratio 1:2 $(\mathrm{w} / \mathrm{v})$ and filtered using cheesecloth. The remain pulp washed and collected together with filtered slurry. This filtered samples which became thinner then incubated for 3 hours at room temperature to allowing starch came out to the medium. Then, the supernatant was decanted off and the wet starch added again with distilled water (ratio 1:2 (w/v)). Thereafter, the precipitation was done twice by incubation at room temperature for 4 hours in order to remove protein and nonstarch components. The clearer water was indicated better precipitation. Finally, the resulting wet starch was dried in an oven at $60{ }^{\circ} \mathrm{C}$ for \pm 6 hours. The dried starch was milled and then sieved using a 100 -mesh sieve as well as packaged before next research steps.

\section{B. Edible film-based fish bone gelatin added with breadfruit starch}

Edible film made from liquid fish bone gelatin. The procedure adopted from Putra et al. (2017) with some modifications [1]. Initially, the fish gelatin from bone of Pangasius catfish which already extracted and stored was placed in room temperature and stirred to obtain liquid form of gelatin. In another laboratory workbench, the breadfruit starch was dissolved with distilled water and sterilized at $75{ }^{\circ} \mathrm{C}$ for 5 minutes. Then, the liquid gelatin mixed with breadfruit starch with different concentrations followed by water addition according to the research treatments (table 1). Afterwards, the mixed solutions were stirred at a temperature of $45{ }^{\circ} \mathrm{C}$, then add $1 \%$ glycerol and stirred again for 30 minutes. Lastly, the solution formulations were poured in silicon paper and dried at $45{ }^{\circ} \mathrm{C}$ for 7 hours using tray dehydrator. The formulation of edible film-based fish gelatin by breadfruit starch addition presented in Table 1 below.

TABLE I

EDIBLE FILM FORMULATIONS

\begin{tabular}{lccccc}
\hline \multicolumn{1}{c}{ Materials } & \multicolumn{5}{c}{ Formulations } \\
\cline { 2 - 6 } & F1 & F2 & F3 & F4 & F5 \\
\hline Fish bone gelatin $(\mathrm{mL})$ & 80 & 75 & 70 & 65 & 60 \\
\hline Breadfruit starch $(\mathrm{g})$ & 2 & 4 & 6 & 8 & 10 \\
\hline Glycerol $(\mathrm{mL})$ & 1 & 1 & 1 & 1 & 1 \\
\hline Distilled water $(\mathrm{mL})$ & 17 & 20 & 23 & 26 & 29 \\
\hline Total Solution & 100 & 100 & 100 & 100 & 100 \\
\hline
\end{tabular}

\section{Moisture content analysis}

The moisture content was analyzed by using oven drying method adopted from AOAC (Association of Official Analytical Chemists) [9]. The empty sample pans were dried in oven for 30 minutes at $105^{\circ} \mathrm{C}$. Then, the pans were chilled in a desiccator to totally ensure that the pans are free from water and then weighed (A). The samples were cut, then weighed as many as 2 grams, after that put in the dried pans (B). Next, the pans containing samples were heated at $105{ }^{\circ} \mathrm{C}$ for 6 hours in the oven. Lastly, the samples were cooled in a desiccator for 30 minutes and weighed (C), this last step was repeated until the constant weight. Moisture content of samples were calculated by using formula below:

$$
\text { Moisture content }(\%)=\frac{\mathrm{B}-\mathrm{C}}{\mathrm{B}-\mathrm{A}} \times 100 \%
$$

\section{Thickness}

Thickness of edible films was measured according to method which described by Amaliya \& Putri (2014). Samples were measured their thickness using plastic digital thickness gauge (accuracy of $0.01 \mathrm{~mm}$ ). There was measured in five different side of films. Thickness was expressed in $\mathrm{mm}$ [10].

\section{E. Tensile Strength and Percent of Elongation}

Tensile strength and percent of elongation were measured using texture analyzer adopted from Rusli et al. (2017) with slightly modification [11]. The samples were cut in size of $7 \mathrm{x}$ $2 \mathrm{~cm}$. After that, the piece of samples was attached in the two tool holders, then set; one immobile (as a holder) and the another movable. The movable handle moved up samples slowly until the films were torn. The force value of movable handle to make films became torn is measured through software on the computer. The tensile strength of the films is calculated by dividing the maximum force to make the film torn $(\mathrm{F})$ with the cross-sectional area of film (A). It is described by formula below:

$$
\text { Tensile Strength }(\mathrm{MPa})=\frac{\mathrm{F}}{\mathrm{A}}
$$

Whilst, the percent of elongation was calculated by dividing the incremental length of the film when became torn at maximum force (b) with the initial length of the films before being pulled (a). Mathematically, it is present in formula below:

$$
\text { Percent of Elongation }(\%)=\frac{\mathrm{b}-\mathrm{a}}{\mathrm{a}} \times 100 \%
$$

\section{F. Water vapor transmission rate (WVTR)}

Water vapor transmission rate was measured based on capacity edible films to hold water vapor. It was adopted from by Shabrina et al. 2017 which started by cutting samples in form of square to allowing them covering top side of beaker glass (the sizes were $7 \times 7 \mathrm{~cm}$ ). The samples stored in desiccator for 24 hours. Then, the water put into beaker glass around $30 \mathrm{ml}$, followed by placed the sample in the top of beaker glass to covered the cup of beaker glass and incubated 
for 24 hours in room temperature. Next, the samples removed from the beaker glass and weighed [12]. The water vapor transmission rate is expressed in $\mathrm{g} / \mathrm{m}^{2}$ /hour and calculated using the formula according to Sukkunta (2005) [13]:

$$
\text { WVTR }=[\mathrm{G} / \mathrm{t}] / \mathrm{A}
$$

\section{Explanation:}

$\mathrm{G} / \mathrm{t}=$ different of weight of sample before and after placed in the top of beaker glass containing water(g)

A $=$ cross-sectional area of sample $\left(\mathrm{m}^{2}\right)$

\section{G. Data analysis}

Ddata was analyzed using a one-way ANOVA Complete Randomized Design (CRD) and continued with Tukey test (significant level of $5 \%$ ) if significantly different.

\section{RESULT AND DISCUSSION}

Previous studies about edible film has been using varieties of raw materials. This research was conducted to characterize edible film made from fish bone gelatin of Pangasius catfish and breadfruit starch. Gelatin that used was extracted by using citric acid during pretreatment step and hot water in the main extraction step [14]. The gelatin which used in this study is in the form of liquid gelatin. While, the starch powder is come from breadfruit. Figure 1 presents the fish gelatin based edible film by different gelatin and starch concentrations. Based on Figure 1, it shows that edible films have similar appearance. However, based on personal observation we found that high concentrations of breadfruit starch have denser structures, but less transparent in their surfaces. It is because the nature of the breadfruit starch itself which will turn yellow when the gelatinization processes occur. Figure 1 also reveals that edible films in all formulations tend to become brown or yellow and less transparent compared than commercial films.

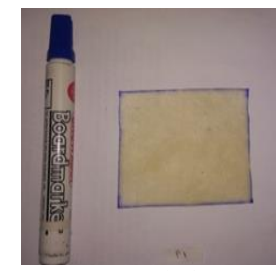

F1 (80\% gelatin; $2 \%$ starch)

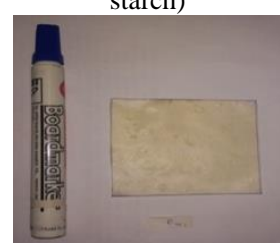

F4 (65\% gelatin; $8 \%$ starch)

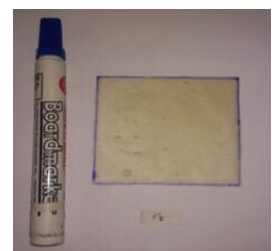

F2 (75\% gelatin; $4 \%$ starch)

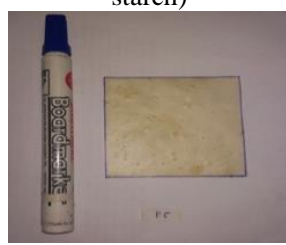

F5 (60\% gelatin; $10 \%$ starch)

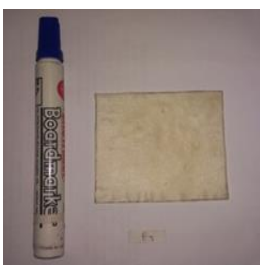

F3 (70\% gelatin; 6\% starch)
Fig. 1 Edible films from fish bone gelatin added breadfruits starch

\section{A. Moisture Content}

Moisture content or water content is one of important requirements in packaging or and edible packaging films. It is effect to the quality of the edible film, because the edible film with less water content is more preferable related amount of water that could be absorbed by their containments. Moisture content of edible film from fish bone gelatin by breadfruit starch addition was $6.08-16.77 \%$. Water content in this study is presented in Figure 2. Based on Figure 2, it can be concluded that moisture content of edible films was reduced by higher concentration of breadfruit addition. It is supported by the theory about starch capacity to absorb water. Starch molecules contain many of hydrophilic group monomers so that their ability to absorb water is also very large [15]. In addition, water content is increasing in samples with higher gelatin percentages. This condition caused by the water which also presence on the liquid form of gelatin. Furthermore, range of water content in this study is lower than edible film from tapioca and gelatin through addition of glycerol as mentioned by Hendra et al. (2015) which around $10.46-13.88 \%$ [6].

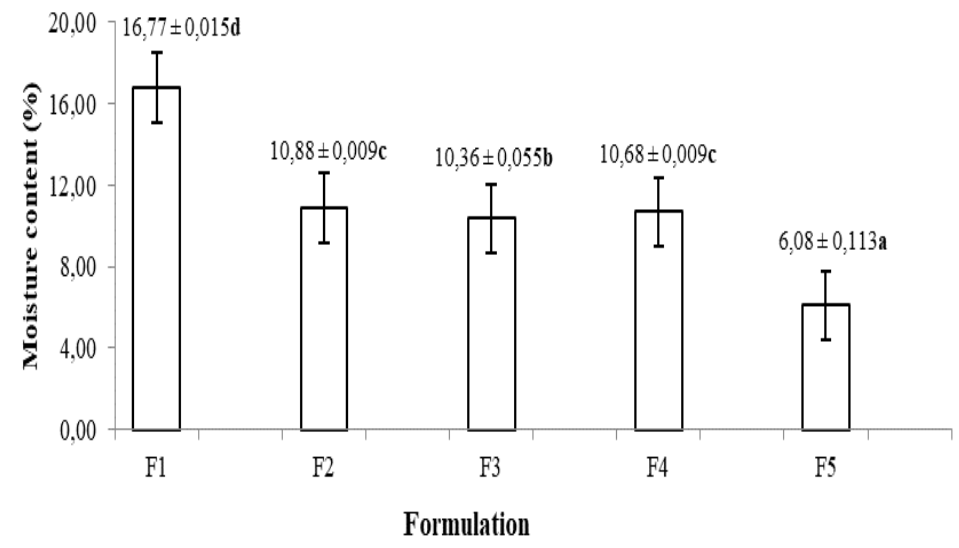

Fig. 2 Moisture content of fish bone gelatin-based edible film. F1 $(80 \%$ gelatin; 2\% starch); F2 (75\% gelatin; 4\% starch); F3 (70\% gelatin; 6\% starch); F4 (65\% gelatin; 8\% starch); F5 (60\% gelatin; 10\% starch). Bars with different letters are significantly different at $\mathrm{p}<0.05$.

\section{B. Thickness}

Thickness is another important parameter that influence of films utilization as packaging of food or edible products. Thickness has effect to the rate of water vapor transmission, tensile strength and percent of elongation of resulting edible films. Thickness analysis result shows that the less gelatin and more starch which were added, make the films became thicker. Edible films in this study have thickness around 0.084 $-0.123 \mathrm{~mm}$ as presented in figure 3 . These values are relatively same with other similar or correlate previous studies. For example, edible film from whey and agar by glycerol addition as a plasticizer have thickness of $0.032-0.036 \mathrm{~mm} \mathrm{[16],}$ whilst, edible films from horse skin gelatin was 0.17 to 0.22 in their thickness [17]. 
Further analysis shows that edible film with $80 \%$ fish bone gelatin and $2 \%$ breadfruit starch was significant different with $60 \%$ fish bone gelatin and $10 \%$ breadfruit starch. This result confirms with Gontard et al. (1993) who stated that the factor which affect the thickness of the edible film is the concentration of dissolved solids in the films solution [18] . Thickness has positive correlation with concentration of dissolved solids. In this study, starch has a role as dissolved solid. Fish bone gelatin based edible film with lowest breadfruit starch addition has smallest the thickness. Actually, the standard plastic film thickness according to Japanese Industrial Standard (JIS) must be maximum $0.25 \mathrm{~mm}$ or below. Edible films in this study met the standard of food packaging films which issued by JIS.

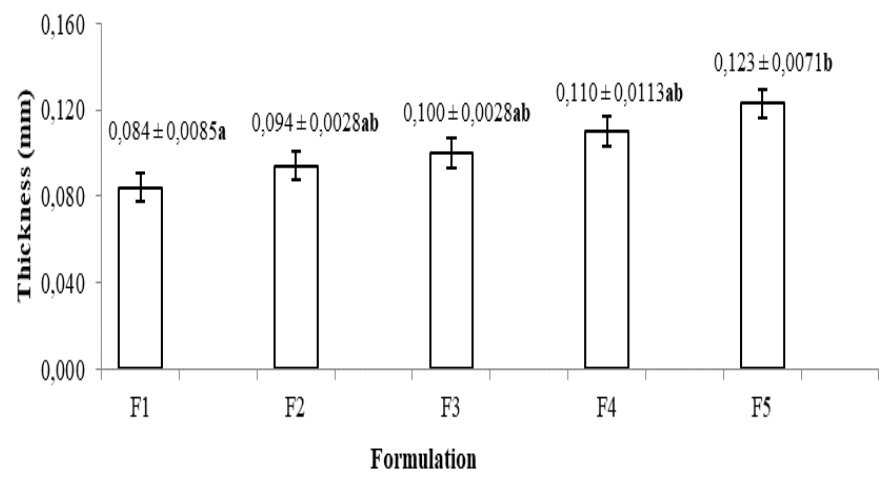

Fig. 3 Thickness of fish bone gelatin-based edible film. F1 $(80 \%$ gelatin; 2\% starch); F2 (75\% gelatin; 4\% starch); F3 (70\% gelatin; 6\% starch); F4 (65\% gelatin; 8\% starch); F5 (60\% gelatin; 10\% starch). Bars with different letters are significantly different at $\mathrm{p}<$ 0.05 .

\section{Tensile strength and percent elongation}

Tensile strength is maximum force which applied where in the same moment the materials become break/torn. Tensile strength is part of physical (mechanical) characteristic of edible film. Films with greater tensile strength is better related their resistance against mechanical forces [19]. The tensile strength of edible films in this study provided in Figure 4. The tensile strength of edible films in this study ranged from 0.245 to $1.186 \mathrm{MPa}$. Statistical analysis shown that edible film from $80 \%$ fish gelatin and $2 \%$ breadfruit starch is different significantly with films made from $65 \%$ fish bone gelatin and $8 \%$ breadfruit starch. Study conducted by Taufik and Fatma (2015) shown that edible films from broiler foot skin is around $2.67-2.94 \mathrm{MPa}$ [20]. Tensile strength of edible film is a physical property related to the strength of edible films to become break or torn when the maximum pull force applied. According to Akili et al. (2012), edible film with higher tensile strength value is expected to be able to protect food or product from mechanical force [21]. According to Japanese Industrial Standard (JIS), standard requirement for tensile strength of films which used as food packaging is $0.39 \mathrm{Mpa}$ or above. So that, we concluded that tensile strength of films this study meets the standard if the concentration of starch which added is around $4-10 \%$.
On the other hand, elongation is deformation that occurs before materials eventually breaks when subjected to a tensile load [22]. Percent of elongation is the change in maximum length at the time of stretching until the material break or torn [23]. Figure 5 presents the percent of elongation edible films from fish bone gelatin with breadfruit starch addition. The result shows that the percent of elongation in this study range from $70 \%$ until $87.14 \%$. These values are significant different each other means that the treatments which given have an impact to the percent of elongation fish gelatin based edible films. Elongation capacity of films in this study is lower than edible films synthetized from gelatin and tapioca in which they have percent of elongation range around 8-108\% [6] However, the deviation value this study much better. This study also has percent of elongation values which confirm with standard from JIS. JIS requires elongation of food packaging film is at least $70 \%$.

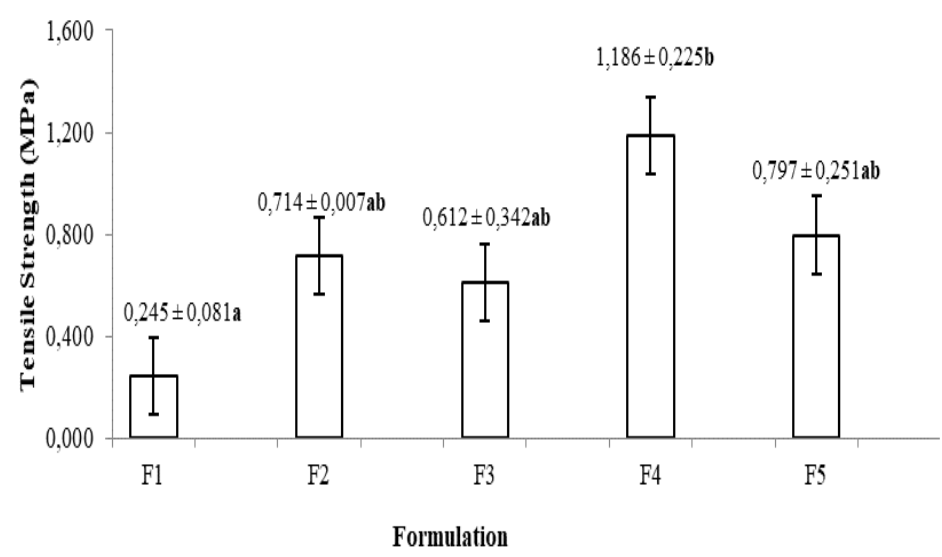

Fig. 4 Tensile strength of fish bone gelatin-based edible film. F1 $(80 \%$ gelatin; 2\% starch); F2 (75\% gelatin; 4\% starch); F3 (70\% gelatin; 6\% starch); F4 (65\% gelatin; 8\% starch); F5 (60\% gelatin; $10 \%$ starch). Bars with different letters are significantly different at $\mathrm{p}<0.05$.

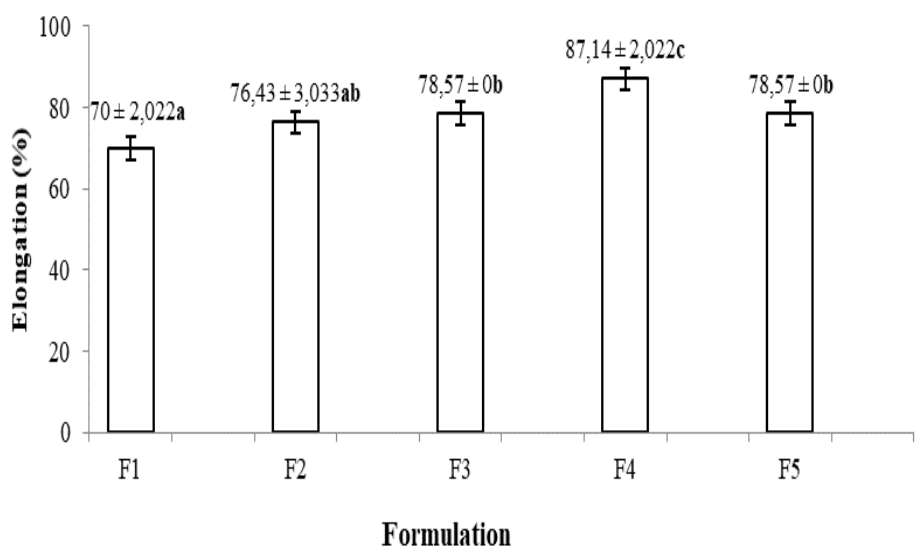

Fig. 5 Elongation degree of fish bone gelatin-based edible film. F1 (80\% gelatin; 2\% starch); F2 (75\% gelatin; 4\% starch); F3 (70\% gelatin; 6\% starch); F4 (65\% gelatin; 8\% starch); F5 (60\% gelatin; 10\% starch). Bars 
with different letters are significantly different at $\mathrm{p}<0.05$.

Actually, a higher percent of elongation indicates that edible film is more flexible. Higher elongation value in films is due to the addition of glycerol which can increasing the intermolecular space stretching in matrix structure so that improving the flexibility, minimaxing the number of hydrogen bonds thereby reducing fragility and will not easily broken. According to Oses et al. (2009), glycerol can interact with polysaccharides by forming a polysaccharide-glycerol bond where this bond will increase the elasticity of both suspensions [24]. However, edible films without plasticizers addition would be very fragile and easily to break [16].

The percent of elongation in edible film has a correlation with the thickness properties. Generally, there are correlation between percent elongation with edible film thickness, in particular case they have positive correlation as described by linear lines in Figure 6 which shows that the increasing of thickness (variable X) implicates to increasing of percent elongation (variable Y).

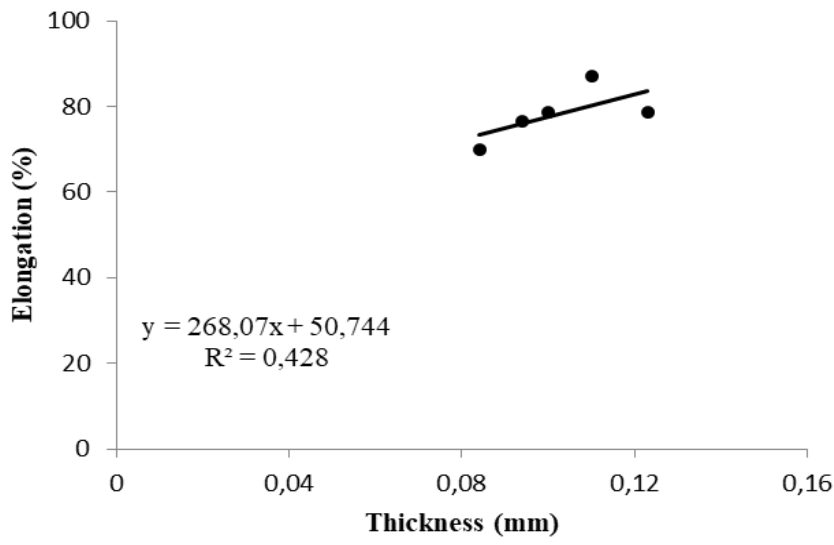

Fig. 6 Correlation between percent of elongation with thickness

\section{Water Vapor Transmission}

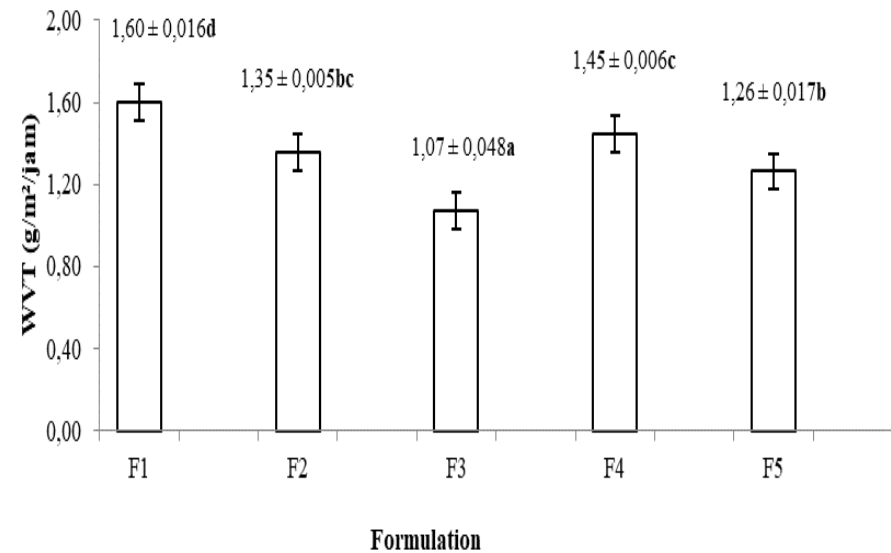

Fig. 7 Water vapor transmission (WVT) of fish bone gelatin-based edible film. F1 (80\% gelatin; 2\% starch); F2 (75\% gelatin; 4\% starch); F3 (70\% gelatin; 6\% starch); F4 (65\% gelatin; 8\% starch); F5 (60\% gelatin; $10 \%$ starch). Bars with different letters are significantly different at $\mathrm{p}<0.05$.

Water vapor transmission (WVT) is the rate of movement of water vapor in a certain time through an area at a certain humidity temperature [25]. The average rate of water vapor transmission in this study ranged from 1.07 to $1.60 \mathrm{~g} / \mathrm{m}^{2} /$ hour as described in figure 7 . These values are greater than edible films from broiler chicken feet namely $0.13-0.30 \mathrm{~g} / \mathrm{m}^{2} /$ hour [20] and lower than edible films from skin gelatin of red tilapia which around $7.21-8.05 \mathrm{~g} / \mathrm{m}^{2} /$ hour. It could be caused by different formulation where the edible films from gelatin of red tilapia skin was using sorbitol and palmitic acid [26]. Furthermore, Figure 7 shows that WVT of edible films from this study affected by the fish gelatin concentration. According to Cho et al (2004), the high value of water vapor transmission rate is associated with high protein content in gelatin-based films [27]. While, based on JIS, the water vapor transmission rate of plastic film which used for food packaging must be maximum $7 \mathrm{~g} / \mathrm{m}^{2} /$ hour indicating this value still confirm with standard.

TABLE II

SUMMARY PHYSICAL PROPERTIES

\begin{tabular}{lrrrr}
\hline $\begin{array}{l}\text { Formu- } \\
\text { lations }\end{array}$ & $\begin{array}{c}\text { Stickness } \\
(\mathrm{mm})\end{array}$ & $\begin{array}{c}\text { WVT } \\
\left(\mathrm{g} / \mathrm{m}^{2} / \mathrm{jam}\right)\end{array}$ & $\begin{array}{c}\text { Tensile } \\
\text { Strength } \\
(\mathrm{MPa})\end{array}$ & $\begin{array}{c}\text { Elongation } \\
(\%)\end{array}$ \\
\hline $\mathrm{F} 1$ & $0,084 \mathrm{a}$ & $1,60 \mathrm{~d}$ & $0,245 \mathrm{a}$ & $70 \mathrm{a}$ \\
\hline $\mathrm{F} 2$ & $0,094 \mathrm{ab}$ & $1,35 \mathrm{bc}$ & $0,714 \mathrm{ab}$ & $76,42 \mathrm{ab}$ \\
\hline $\mathrm{F} 3$ & $0,100 \mathrm{ab}$ & $1,07 \mathrm{a}$ & $0,612 \mathrm{ab}$ & $78,57 \mathrm{~b}$ \\
\hline $\mathrm{F} 4$ & $0,110 \mathrm{ab}$ & $1,45 \mathrm{c}$ & $1,186 \mathrm{~b}$ & $87,14 \mathrm{c}$ \\
\hline $\mathrm{F} 5$ & $0,123 \mathrm{~b}$ & $1,26 \mathrm{~b}$ & $0,797 \mathrm{ab}$ & $78,57 \mathrm{~b}$ \\
\hline Japanese & & & min & \\
$\begin{array}{l}\text { Industrial } \\
\text { Standard } \\
\text { (JIS)* }\end{array}$ & maks 0,25 & maks 7 & 0,39 & $\min 70$ \\
\hline
\end{tabular}

F1 (80\% gelatin; 2\% starch); F2 (75\% gelatin; 4\% starch); F3 (70\% gelatin; 6\% starch); F4 (65\% gelatin; 8\% starch); F5 (60\% gelatin; $10 \%$ starch). Values in the same row (F1 - F5) followed by different letters are significant differents $(\mathrm{P}<0.05)$.

*Fatnasari et al. (2018)

\section{CONCLUSION}

Edible films synthetized from fish bone gelatin of Pangasius catfish by breadfruit starch addition have thickness values ranged $0.084-0.123 \mathrm{~mm}, 6.08-16.77 \%$ of moisture content, water vapor transmission of $1.07-1.60 \mathrm{~g} / \mathrm{m}^{2} / \mathrm{hour}$, tensile strength of $0.245-1.186 \mathrm{MPa}$, and percent of elongation around $70-87.14 \%$. In addition, edible gelatin films from gelatin of Pangasius catfish bone with breadfruit starch addition confirm the standards of plastic film according to Japanese Industrial Standard (JIS) 


\section{REFERENCES}

[1] A. Dwi Putra, V. Setiaries Johan, and R. Efendi, "Penambahan sorbitol sebagai plasticizer dalam pembuatan edible film pati sukun," JOM Fak. Pertan., vol. 4, no. 2, pp. $1-15,2017$.

[2] V. Trinetta, Edible packaging, vol. 59, no. 2. Minnesota: Elsevier, 2016.

[3] Hariyanto and Y. J. Sambudi, "Pembuatan Gelatin dari Tulang Ikan Air Tawar (Anabantidae)," Surakarta, 2010.

[4] N. Da Silva E Silva, E. J. G. Pino Hernández, C. Da Silva Araújo, M. R. S. Peixoto Joele, and L. de F. H. Lourenço, "Development and optimization of biodegradable fish gelatin composite film added with buriti oil," CYTA - J. Food, vol. 16, no. 1, pp. 340-349, 2018, doi: 10.1080/19476337.2017.1406005.

[5] M. Cornelia, N. A. Anugrahati, and Christina, "Pengaruh penambahan pati bengkoang terhadap karakteristik fisik dan mekanik edible film," J. Kim. Kemasan, vol. 34, no. 2, pp. 263-271, 2012.

[6] A. A. Hendra, A. R. Utomo, and E. Setijawati, "Kajian karakterisitik edible film dari tapioka dan gelatin dengan perlakuan penambahan gliserol," J. Teknol. Pangan dan Gizi, vol. 14, no. 2, pp. 95-100, 2015.

[7] M. Hasdar, Y. Erwanto, and S. Triatmojo, "Karakteristik edible film yang diproduksi dari kombinasi gelatin kulit kaki ayam dan soy protein isolate," Bul. Peternak., vol. 35, no. 3, pp. 188-196, 2011.

[8] T. O. Akanbi, S. Nazamid, and A. A. Adebowale, "Functional and pasting properties of a tropical breadfruit (Artocarpus altilis) starch from Ile-Ife, Osun state, Nigeria," Int. Food Res. J., vol. 16, no. 2, pp. 151-157, 2009.

[9] R. L. Bradley, Food Analysis, 4th ed. New York: Springer, 2010.

[10] R. R. Amaliya and W. D. R. Putri, "Karakterisasi edible film dari pati jagung dengan penambahan filtrat kunyit putih sebagai antibakteri," J. Pangan dan Agroindustri, vol. 2, no. 3, pp. 43-53, 2014.

[11] A. Rusli, Metusalach, Salengke, and M. M. Tahir, "Karakterisasi edible film karagenan dengan pemlastis gliserol," J. Pengolah. Has. Perikan. Indones., vol. 20, no. 2, pp. 219-229, 2017.

[12] A. N. Shabrina, S. B. M. Abduh, A. Hintono, and Y. Pratama, "Sifat fisik edible film yang terbuat dari tepung pati umbi garut dan minyak sawit," J. Apl. Teknol. Pangan, vol. 6, no. 3, pp. 138-142, 2017, doi: 10.17728/jatp.239.

[13] S. Sukkunta, "Physical and Mechanical Properties of Chitosan-Gelatin Based Film," Mahidol Univesity, 2005.

[14] M. Pertiwi, Y. Atma, A. Z. Mustopa, and R. Maisarah, "Karakteristik fisik dan kimia gelatin dari tulang ikan patin dengan pre- treatment asam sitrat," J. Apl. Teknol. Pangan, vol. 7, no. 2, pp. 83-91, 2018.
[15] D. H. Kusumawati and W. D. R. Putri, "Karakteristik fisik dan kimia edible film pati jagung yang diinkorporasi dengan perasan temu hitam," J. Pangan dan Agroindustri, vol. 1, no. 1, pp. 90-100, 2013, [Online]. Available: http://jpa.ub.ac.id/index.php/jpa/article/view/9.

[16] S. H. Ningsih, "Pengaruh Plasticizer Gliserol Terhadap Karakteristik Edible Film Campuran Whey dan Agar," Universitas Hasanuddin, 2015.

[17] D. T. Gela, "Karakteristik Edible Film dari Gelatin Kulit Kuda (Equus caballus) serta Aplikasinya untuk Kemasan Pangan," UIN Alauddin Makassar, 2016.

[18] N. Gontard, S. Guilbert, and J.-L. Cuq, "Water and glycerol as plasticizers affect mechanical and water vapor barrier properties of an edible wheat gluten film," J. Food Sci., vol. 58, no. 1, pp. 206-211, 1993, doi: 10.1111/j.13652621.1993.tb03246.x.

[19] J. L. Audic, F. Fourcade, and B. Chaufer, "Biodegradable material obtained from renewable resource: Plasticized sodium caseinate films," in Thermodynamics, Solubility and Environmental Issues, 1st ed., T. Letcher, Ed. Elsevier B.V., 2007, pp. 369-382.

[20] M. Taufik and Fatma, "Karakteristik edible film berbahan dasar gelatin kulit kaki broiler," in Seminar Nasional Peternakan, 2017, pp. 220-228.

[21] M. S. Akili, U. Ahmad, and N. E. Suyatma, "Karakteristik edible film dari pektin hasil ekstraksi kulit pisang," $J$. Keteknikan Pertan., vol. 26, no. 1, pp. 39-46, 2011.

[22] D. Roylance, Mechanical Properties of Materials. 2008.

[23] B. T. R. I. Harsunu, "Pengaruh Konsentrasi Plasticizer Gliserol dan Komposisi Khitosan dalam Zat Pelarut Terhadap Sifat Fisik Edible Film dari Khitosan," Universitas Indonesia, 2008.

[24] J. Osés, I. Fernández-Pan, M. Mendoza, and J. I. Maté, "Stability of the mechanical properties of edible films based on whey protein isolate during storage at different relative humidity," Food Hydrocoll., vol. 23, no. 1, pp. 125-131, 2009, doi: 10.1016/j.foodhyd.2007.12.003.

[25] R. K. Basha, K. Konno, H. Kani, and T. Kimura, "Water vapor transmission rate of biomass based film materials," Eng. Agric. Environ. Food, vol. 4, no. 2, pp. 37-42, 2011, doi: 10.1016/S1881-8366(11)80018-2.

[26] G. E. Julianto, Ustadi, and A. Husni, "Karakteristik edible film dari gelatin kulit Nila merah dengan penambahan plasticizer sorbitol dan asam palmitat," J. Perikan., vol. 13, no. 1, pp. 27-34, 2011, doi: 10.22146/jfs.3059.

[27] S. M. Cho et al., "Processing optimization and functional properties of gelatin from shark (Isurus oxyrinchus ) cartilage," Food Hydrocoll., vol. 18, pp. 573-579, 2004, doi: 10.1016/j.foodhyd.2003.10.001. 